\title{
Isolation of Corynebacterium Species from Retail Mutton and Lamb in the North West Province, South Africa
}

\author{
Sicelo Beauty Dlamini, Collins Njie Ateba* \\ Department of Biological Sciences, School of Environmental and Health Sciences, Faculty of Agriculture, Science and Technology, \\ North West University- Mafikeng Campus, Private Bag X2046, Mmabatho 2735, South Africa \\ *Corresponding author: atebacollins1@hotmail.com
}

Received April 12, 2014; Revised June 20, 2014; Accepted July 13, 2014

\begin{abstract}
Corynebacterium species occur as part of the normal flora of animals and humans and there is very little information on the diversity and host range of these pathogens. Despite this, some Corynebacterium species have been reported to cause infections in both animals and humans. Infections usually result from the consumption of contaminated food products such as meat and milk as well as contact with infected animals. The aim of study was to isolate, identify and characterize Corynebacterium species from retail meat products obtained from some supermarkets in the North West Province, South Africa. A total of 25 mutton and lamb meat samples were purchased from some supermarket and butcheries in the North West Province, South Africa and bacteria was isolated using Colombia agar supplemented with $5 \%(\mathrm{w} / \mathrm{v})$ bovine blood. Seventy five presumptive Corynebacterium isolates were obtained based on colonial morphology and these isolates were screened for characters of Corynebacterium species. Amongst these, 67 isolates were catalase positive while 54 were Gram positive rods. Twenty four representative isolates were not able to utilize urea and ferment glucose and maltose respectively. However 19 (79.2\%) of these isolates were able to utilize nitrate and33\% were positively identified as Corynebacterium species using API Coryne assay. Eleven percent of the isolates were positively identified as Corynebacterium species by $16 \mathrm{~S}$ specific rRNA PCR analysis. From these results it was evident that Corynebacterium species were present in the raw meat products and the meat products could pose severe health risks to consumers, especially individuals who are immuno-compromised. This therefore amplifies the need to implement strict measures that limit the transmission of these pathogens through the food chain to consumers. Moreover, constant assessments of the health risks associated with contaminated food products in the South African market should be performed on routine basis.
\end{abstract}

Keywords: Corynebacterium species, $16 \mathrm{~S}$ rRNA, mutton and lamb, PCR analysis

Cite This Article: Sicelo Beauty Dlamini, and Collins Njie Ateba, "Isolation of Corynebacterium Species from Retail Mutton and Lamb in the North West Province, South Africa." Journal of Food and Nutrition Research, vol. 2, no. 7 (2014): 377-382. doi: 10.12691/jfnr-2-7-8.

\section{Introduction}

Corynebacterium is genus within the phylum Actinobacteria and the order Actinomycetales and it involves a heterogeneous group of approximately 60 species that are easily differentiated through chemical analysis [1]. Bacteria belonging to the genus Corynebacterium can be found in a wide range of ecological niches such as dairy products, soil, sewage, plant surfaces, and aquatic environments [2]. Bacteria in this genus have morphological resemblance to diphtheria bacillus [3]. Corynebacterium species share phenotypic traits that are easily determined and these include positive reactions for the catalase test, Gram positive rod shaped, pleomorphic, non-spore forming, non-motile, and nonacid fast bacilli [4].

Corynebacterium species also occur as normal flora in humans and animals $[1,5,6]$. However, there is very little information on the diversity and host range of this bacteria species in many parts of the world [1,5,6]. Previously nondiphtheria Corynebacterium species were considered to be none pathogenic strains within the genus. However, they have recently been recognized as pathogenic organisms, which cause severe health problems in individuals especially those who are immuno-compromised and with indwelling catheters [7].

Corynebacterium species cause diseases respiratory tract, wound and skin infections in humans $[3,8]$. These bacteria are easily transmitted through droplets, contact contaminated mucous membranes and skin abrasions [8]. Moreover, toxigenic stains may produce toxins that are responsible for the pathological conditions associated with Corynebacterium species [8]. Human infections also result the consumption of contaminated food products such as raw milk as well as undercooked meat [9-15]. Therefore an evaluation of the occurrence of these organisms in food products may provide information on the health risks that may result in consumers. Moreover, a determination of the genetic fingerprints of isolates from different sources may have huge epidemiological value. 


\section{Materials and Methods}

\subsection{Area of the Study}

This study was conducted at North West University (Mafikeng Campus), North West Province. A total of 25 mutton and lamb samples were bought from some supermarkets and butcheries in the North West Province, South Africa. Table 1 indicates the number of meat samples collected from different sampling areas.

\subsection{Sampling Regime and Area}

A total number of 25 samples (mutton and lamb) were collected from different butcheries and supermarkets in the North West Province, South Africa. Samples were collected in sterile plastic bags and transported on ice to the laboratory for analysis. Colombia agar base supplemented with $5 \%(\mathrm{w} / \mathrm{v})$ bovine blood was used to isolate the target organisms from meat samples.

Table 1. Areas from which beef (meat) samples were collected

\begin{tabular}{|l|l|}
\hline Sampling area & Number of samples \\
\hline Potchefstroom & 3 \\
\hline Mafikeng & 14 \\
\hline Carletonville & 4 \\
\hline Coligny & 1 \\
\hline Lichtenburg & 3 \\
\hline
\end{tabular}

\subsection{Isolation of the Bacteria}

\subsubsection{Isolation of Bacteria}

Two grams of mutton and lamb meat samples were aseptically cut with a sterile blade washed in $5 \mathrm{~mL}$ of sterile $2 \%(\mathrm{w} / \mathrm{v})$ peptone water. An aliquot of $100 \mu \mathrm{L}$ from each sample was spread plated on Colombia agar base supplemented with $5 \%(\mathrm{w} / \mathrm{v})$ bovine blood. The plates were incubated microaerophilically $\left(10 \% \mathrm{CO}_{2}\right)$ at $37^{\circ} \mathrm{C}$ for 72 hours. After incubation, 3 presumptive colonies from each sample were sub-cultured on Colombia agar and plates were incubated microaerophilically $\left(10 \% \mathrm{CO}_{2}\right)$ at $37^{\circ} \mathrm{C}$ for 72 hours. Pure isolates were stored at room temperature and used for bacteria identification tests.

\subsection{Bacterial Identification}

Isolates were identified as Corynebacterium species using the following criteria:

\subsubsection{Cellular Morphology}

Isolates were Gram stained using standard techniques [4]. Gram positive rods were subjected to preliminary biochemical and confirmatory identification tests.

\subsubsection{Catalase Test}

The catalase test is commonly used to determine the presence of the catalase enzyme which degrades toxic hydrogen peroxide $\left(\mathrm{H}_{2} \mathrm{O}_{2}\right)$ in cells containing the cytochrome oxidase system. A pure colony was transferred onto the surface of a microscopic slide using a sterile inoculating needle. A drop of 3\% hydrogen peroxide was added and the slide was observed for the presence of bubbles. The results were recorded in the data sheet and all isolates that were catalase positive were presumptively considered to be Corynebacterium species.

\subsubsection{API Coryne for Confirmatory Identification of Corynebacterium Species}

The identities of all presumptive Corynebacterium isolates were confirmed using the API Coryne assay kit. The test was performed according to the manufacturer's instructions (Bio-Mérieux ${ }^{\circledR}$, France). The tests performed included nitrite reduction, hydrolysis of urea and esculin, fermentation of sugars, and expression of the enzymes pyrazinamidase and alkaline phosphatase that are specific for the genera Corynebacterium [5,16]. Results were read with or without the addition of reagents and indices were generated. Results were interpreted using the API web software obtained from Bio-Mérieux ${ }^{\circledR}$, S.A [5].

\section{Genomic DNA extraction}

Genomic DNA was extracted from all presumptive Corynebacterium isolates using Zymo Research Genomic DNA $^{\mathrm{TM}}$-Tissue MiniPrep kit (Catalog No. D3051-USA supplied by Biolab, South Africa) according to the manufacturer instructions. Pure isolates from Colombia agar base were inoculated into $5 \mathrm{~mL}$ of nutrient broth and incubated aerobically at $37^{\circ} \mathrm{C}$ for 24 hours while shaking. Briefly, $100 \mu \mathrm{L}$ from the broth cultures were transferred into $1.5 \mu \mathrm{L}$ sterile eppendorf tubes in which $95 \mu \mathrm{L} 2 \mathrm{X}$ digestion buffer and $5 \mu \mathrm{L}$ of Proteinase $\mathrm{K}$ were also added. The contents of the tube were vortexed and incubated at $55^{\circ} \mathrm{C}$ for 20 minutes using pre-heated dry bath (Digital dry heat, Bio-Rad). After incubation, $700 \mu \mathrm{L}$ of Genomic Lysis Buffer was added to the tubes and thoroughly mixed by vortexing vigorous. The mixture was transferred into a Zymo-Spin ${ }^{\text {TM }}$ IIC column present in a collection tube and centrifuged at $13500 \mathrm{rpm}$ for 1 minute in a Heraeus microfuge (Kendro, Germany). The supernatant was discarded and $200 \mu \mathrm{L}$ DNA Pre-buffer was added to the spin column present in a new collection tube. The tubes were centrifuged at $13500 \mathrm{rpm}$ for 1 minute and the supernatant was discarded. An aliquot of $400 \mu \mathrm{L}$ of the gDNA Wash Buffer was added to the spin column and centrifuged at 13500 rpm for 1 minute. The supernatant was discarded and100 $\mu \mathrm{L}$ of DNA Elution Buffer was added to the spin column that was transferred to a new collection tube. The tube was incubated for 2-5 minutes at $37^{\circ} \mathrm{C}$ and later centrifuged at $13500 \mathrm{rpm}$ for 30 seconds to elute the DNA. DNA samples were stored at $-20^{\circ} \mathrm{C}$ and used for molecular identification assays.

\section{Molecular identification}

PCR for amplification of 16S rRNA gene specific sequences in Corynebacterium species fragments

Designated primer pairs F (5'TGGCTCAGATTGAACGCTGGCGGC-3') and 16S rRNA R (5'-TACCTTGTTACGACTTCACCCCA-3') were used to amplify Corynebacterium species specific 16S rRNA gene fragments [17]. Amplifications were carried out using a C1000 Touch ${ }^{\mathrm{TM}}$ Thermal Cycler (BioRad, Johannesburg, South Africa. PCR amplification was performed in a total volume of $25 \mu \mathrm{L}$ made up of $12.5 \mu \mathrm{L}$ master mix (Thermo scientific PMM), 8.5 $\mu$ l of nuclease free water, $1.5 \mu \mathrm{L}$ of loading buffer, $0.5 \mu \mathrm{L}$ oligonucleotide primer set and finally, $2 \mu \mathrm{L}$ of DNA template. All the reagents were obtained from Inqaba Biotec Ltd, Sunnyside- South Africa. The thermocycling conditions were as follows: denatured at $95^{\circ} \mathrm{C}$ for 5 minutes, 35 
cycles of $95^{\circ} \mathrm{C}$ for 45 seconds, $55^{\circ} \mathrm{C}$ for 45 seconds, $72^{\circ} \mathrm{C}$ for 1 minute and a final extension at $72^{\circ} \mathrm{C}$ for 10 minutes. The PCR products were stored at $4^{\circ} \mathrm{C}$ before separation by electrophoresis.

\section{ERIC-PCR fingerprinting}

The strains of Corynebacterium species identified were fingerprinted by RAPD using the primers ERIC-1R (5'ATGTAAGCTCCTGGGGATTCAC-3') and ERIC-2 (5' AAGTAAGTGACTGGGGTGAGCG-3' ) [18]. Optimal reaction mixture was $25.0 \mu \mathrm{L}$ containing 1 XPCR master mix, $2 \mu \mathrm{L}$ of template DNA, $0.5 \mu \mathrm{L}$ of primer, $8.5 \mu \mathrm{L}$ nuclease free water and $1.5 \mu \mathrm{L}$ buffer $10 \mathrm{X}$ reaction. Amplifications were performed on a DNA thermal cycler (C1000 Touch ${ }^{\mathrm{TM}}$, BIO-RAD, South Africa). Thermocycling conditions used consisted of the following initial denaturation of $94^{\circ} \mathrm{C}$ for 2 minutes, followed by 2 cycles at $94^{\circ} \mathrm{C}$ for 30 seconds, $37^{\circ} \mathrm{C}$ for $1 \mathrm{~min}$ and $72^{\circ} \mathrm{C}$ for 2 minutes. This was followed by 41 cycles of $93^{\circ} \mathrm{C}$ for 30 seconds, $35^{\circ} \mathrm{C}$ for 1 minute and $72^{\circ} \mathrm{C}$ for 2 minutes, and a final extension at $72^{\circ} \mathrm{C}$ for 5 minutes.

\section{Electrophoresis of PCR Products}

The PCR products were resolved by electrophoresis on a $2 \%(w / v)$ agarose gel, for both toxic genes and housekeeping genes. A horizontal Pharmacia biotech equipment system (model Hoefer HE 99X; Amersham Pharmacia biotech, Sweden) was used to carry out electrophoresis and this was run at 100 volts for 10 minutes and 80 volts for 45 minutes using $1 \mathrm{x}$ TAE buffer (40mM Tris, 1mM EDTA and 20mM glacial acetic acid, PH 8.0). Each 16S rRNA and ERIC PCR gel contained a $1 \mathrm{~kb}$ and 100bp DNA molecular weight marker (Fermenters, USA) respectively. The gels were stained in ethidium bromide $(0.1 \mu \mathrm{g} / \mathrm{mL})$ for 15 minutes and amplicons were visualized under U.V light at $420 \mathrm{~nm}$ wavelength. A Chemo Doc imaging system (Bio-Rad Chemo Doc $^{\mathrm{TM}}$ MP imaging system, UK) was used to capture the image using GeneSnap (version 6.00.22) software. GeneTools (version 3.07.01) software (Syngene, Synopties; UK) was used to analyze the images in order to determine the relative sizes of the amplicons.

\section{Results and Interpretation}

\subsection{Detection of Corynebacterium Species in Mutton and Lamb Samples Using Preliminary and Confirmatory Biochemical Tests}

Twenty five mutton and lamb samples were analyzed for the presence of Corynebacterium species using Colombia agar base supplemented with $5 \%$ bovine blood. A total of 75 presumptive Corynebacterium isolates were obtained during the study and representative isolates were screened for characters of Corynebacterium species. Of these a total of $67(89 \%)$ isolates were positive for the catalase test while 54 (72\%) were Gram positive rods. A total of 24 representative isolates were not able to utilize urea while all these isolates were able to ferment glucose and maltose. However, 5 of the 24 isolates were not able to utilize nitrate. Only $33 \%$ of these isolates were positively identified as Corynebacterium species using API Coryne assay. The results of the present study indicated that Corynebacterium species was most often isolated from samples obtained from supermarkets and butcheries in Mafikeng (21\%) and Carletonville (8\%). Despite this, samples obtained from Potchefstroom showed some level (4\%) of Corynebacterium contamination. However, the identification of isolates belonging to the genus Corynebacterium was a cause for concern. These findings indicated that meat products obtained from supermarkets and butcheries may potentially cause food-borne infections if they are consumed undercooked.

\subsection{PCR Analysis for the Detection of Corynebacterium Species}

To amplify Corynebacterium species specific sequences genomic DNA was extracted from 54 presumptive isolates and Figure 1 shows a $2 \% \quad(\mathrm{w} / \mathrm{v})$ agarose gel electrophoresis of representative isolates. DNA obtained was of good quality with no fragmentation observed.

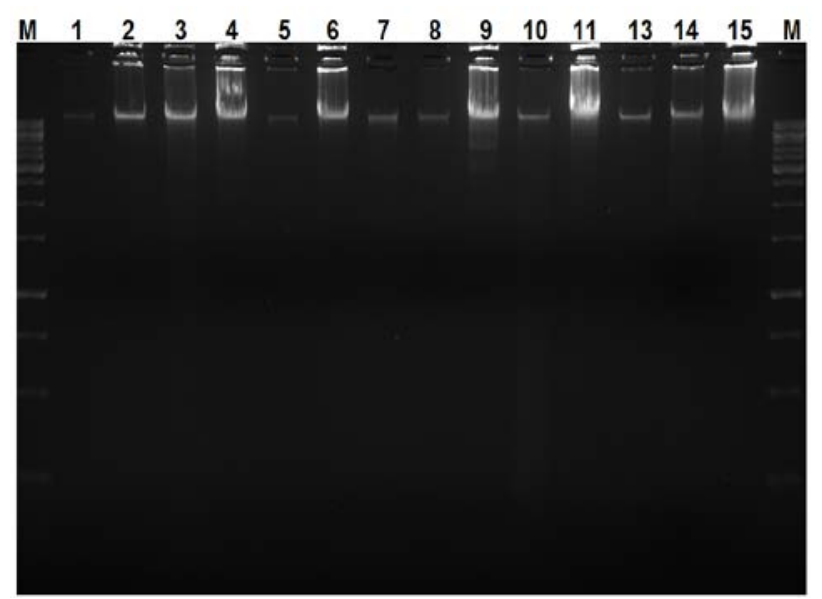

Figure 1. Genomic DNA extracted from isolates. Lane $\mathrm{M}=1 \mathrm{~kb}$ DNA marker; Lanes 1-15= genomic DNA extracted from all positive isolate

\subsection{Specific PCR for the Detection of $16 \mathrm{~S}$ rRNA Gene Fragment in Corynebacterium Species}

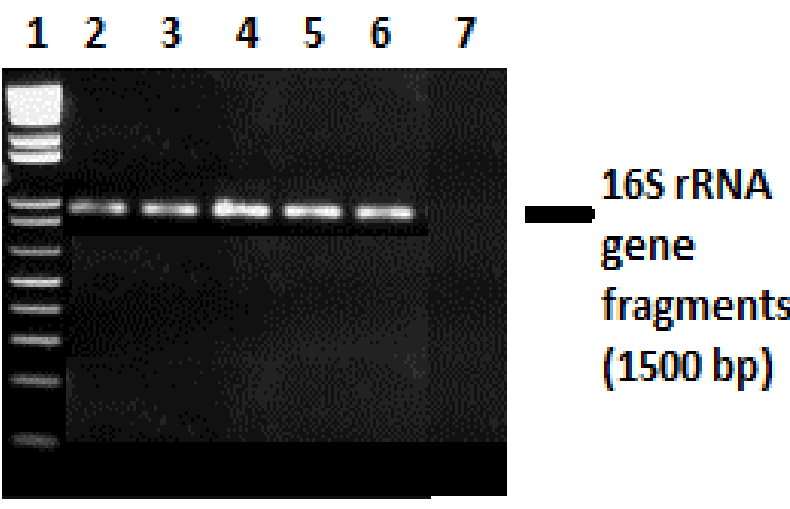

Figure 2. PCR for the detection of Corynebacterium species specific $16 \mathrm{~S}$ rRNA gene composite gel electrophoresis. Lane $1=1 \mathrm{~kb}$ DNA maker; lane $2=$ specific $16 \mathrm{~S}$ rRNA gene from Corynebacterium species isolated from mutton sample in Lichtenburg and Lanes 3-6= specific 16S rRNA gene from Corynebacterium species isolated from mutton and lamb samples in Potchefstroom, Lane $7=$ No template DNA reaction tube

A total of 54 isolates that satisfied both preliminary and confirmatory identification tests were subjected to simplex specific PCR analysis for the detection of 
Corynebacterium species specific 16S rRNA gene fragments. This gene encodes for conserved signature proteins which are unique to the genus Corynebacterium [20,21]. These proteins are known to facilitate clustering of organisms belonging to the genus Corynebacterium on a phylogenetic tree. Only a small proportion (11\%) of the potential Corynebacterium isolates were positively identified by specific $16 \mathrm{~S}$ rRNA PCR analysis. Figure 2 shows a $2 \%(\mathrm{w} / \mathrm{v})$ agarose gel electrophoresis image depicting the 16S rRNA gene fragments that were amplified by PCR using genomic DNA extracted from all isolates. Fragments with the expected amplicon size of 1500bp were obtained.

Table 2. Number of Corynebacterium species isolates that were positive for the targeted genes

\begin{tabular}{|l|c|c|}
\hline Sample area & $\begin{array}{l}\text { No of isolates } \\
\text { tested }\end{array}$ & $\begin{array}{l}\text { No of isolates positive for } \\
\text { the targeted genes (16S } \\
\text { rRNA) }\end{array}$ \\
\hline Potchefstroom & 9 & 5 \\
\hline Mafikeng & 21 & 0 \\
\hline Carletonville & 12 & 0 \\
\hline Coligny & 3 & 0 \\
\hline Lichtenburg & 9 & 1 \\
\hline TOTAL & 54 & 6 \\
\hline
\end{tabular}

\subsection{ERIC Genotypes}

Fifty four strains of Corynebacterium species from mutton and lamb meat products were fingerprinted by ERIC-PCR and all strains compared were always included in a single run in order to avoid misinterpretation problems associated with interassay variability. Specific fingerprints were generated and the amplicons were separated on a $2 \%$ agarose (w/v) gel electrophoresis (Figure 3). The band patterns obtained for each isolate was used to determine the degree of similarity between isolates from different sampling sites. As shown in Figure 3, bands produced ranged from one to five for different isolates and the amplicon sizes ranged from 250bp to 1000bp. Six genotypes were obtained when using both ERIC PCR primers and the banding patterns were used to determine similarities between isolates.

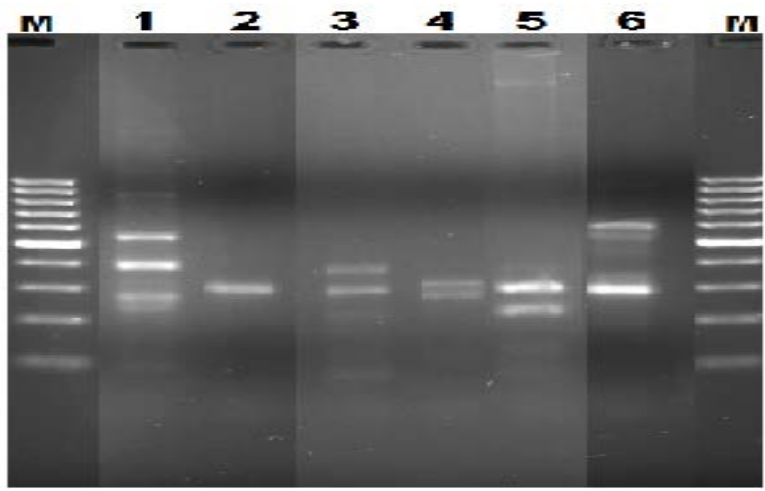

Figure 3. ERIC PCR analysis for Corynebacterium species composite gel electrophoresis. Lanes M=100bp DNA marker; Lane 1 and 6= ERIC profiles of Corynebacterium species isolated from mutton and lamb samples in Carltonville; Lane 2= ERIC profiles of Corynebacterium species isolated from mutton and lamb samples in Lichtenburg; Lane 3= ERIC profiles of Corynebacterium species isolated from mutton and lamb samples in Carltonville; Lane $4=$ ERIC profiles of Corynebacterium species isolated from mutton and lamb samples in Mafikeng and Lane 5= ERIC profile of Corynebacterium species isolated from mutton and lamb samples in Potchefstroom

\section{Discussions}

The primary objective of the study was to isolate and identify Corynebacterium species from retail mutton and lamb meat samples obtained from supermarkets and butcheries in the North West Province, South Africa. This was motivated by the fact that some food products such as meat, milk and milk products has been implicated as the cause of Corynebacterium species contamination in the food chain [9-15]. Despite the fact that foodborne outbreaks of Corynebacterium species infections have not been reported to date in South Africa the pathogens have been isolated from animals, humans, and food products even in countries with advanced healthcare and public health facilities [13,22,23,24,25,26]. The implication of this is that if hygiene measures are not fully implemented either during the slaughtering of animals or the processing and preparation of food products this might provide opportunities for these contaminated food products to serve as a potential source for the transmission of Corynebacterium species to consumers. This may therefore have severe health consequences on humans in the area.

In some developed countries, a number of Corynebacterium species have been isolated from humans and animals [2,3,5,6,7,9,27-32]. Although in some cases it is difficult to link infections with the source of contamination, there is evidence that these organisms are highly prevalent in sheep and goat populations [33,34]. Corynebacterium species cause diseases in these animal species that account for a significant economic loss worldwide [35]. Unfortunately, the actual incidence of diseases caused by Corynebacterium species is usually underestimated since it is not a notifiable disease in many countries. The natural hosts of Corynebacterium species are domestic animals and transmission of these bacteria to humans usually occur through contact with infected animals and the consumption of contaminated food such as milk there is need to determine their occurrence in animals and food sources. To the best of our knowledge there is currently very little information on the prevalence of these organisms in food products and their associated virulence determinants in Africa [13]. South Africa is no exception and lack of information on the occurrence of Corynebacterium species in South Africa among humans, animals as well as food products, amplifies the need to evaluate food products for the presence of these pathogens in order to access the health risks they may pose on consumers [14,32].

In the present study, Corynebacterium species were successfully isolated and identified in some of the mutton and lamb samples. Based on available data this is the first study in the North West Province in which Corynebacterium species has been isolated from food products (mutton and lamb). Isolates were more prevalent in samples purchased in Potchefstroom and Lichtenburg. These species can cause diseases such as diphtheria if consumed in contaminated food products [11,12,32,35].

Despite the fact that Corynebacterium species differ with respect to virulence or pathogenicity in their hosts, all pathogenic strains are of severe health concern, especially if isolated from food products that are intended for human consumption. Therefore the results obtained in the present study indicate that these food products may have 
significant public health implications on consumers. Moreover, considering the incidence of HIV/AIDS in the country disease causing organisms including Corynebacterium that usually present more severe complications on immuno-compromised individuals, those in poverty stricken communities and hospitalized personnel must be monitored constantly $[4,7,36]$. Moreover, there is need to implement strict measures during the handling of meat especially in the supermarkets [37]. Even though PCR methods have proven to be very reliable in identifying microbes including Corynebacterium species, conventional microbiology methods have also been used to determine the identity of these isolates. In the present study, large proportions of isolates (72\% to $89 \%$ ) were Gram positive rods and catalase positive. Similar observations have been reported $[12,13]$. None of the isolates utilized urea a large proportion (80\%) was positive for nitrate reduction. Similar observations have been reported for Corynebacterium diphtheria and other potential toxigenic Corynebacterium species [19]. Moreover, the carbohydrate fermentation trend observed for glucose and maltose have also been previously reported for Corynebacterium species [23]. Among the representative isolates from Potchefstroom, Mafikeng, Coligny, Lichtenburg and Carletonville 33\% were positively identified using API Coryne test and this assay has been used to effectively identify Corynebacterium species $[23,38]$. Despite the fact that virulent gene profiles of the Corynebacterium species were isolated from retail meat (mutton and lamb) were not determined, the different species have been reported to have severe implications on consumers $[7,36,39,40]$ and this was a cause for concern.

Another objective of the study was to determine the presence of 16S rRNA gene fragments specific to Corynebacterium species using simplex specific PCR analysis. The 16S rRNA gene sequence analysis is a reliable tool for identifying Corynebacterium strains [41] and the 16S rRNA gene has been used to successfully cluster Corynebacterium isolates from different sources into a phylogenetic tree [42]. In the present study, $11 \%$ of the isolates were positively identified for the 16S rRNA gene fragment which is specific for Corynebacterium species and similar observations were reported [13]. These results indicate that there is a need for more detailed studies to be conducted in which these Corynebacterium species will be isolated from animals, their corresponding food products and humans. This may provide an indication of the health risks associated with these products in the South African context.

A further objective of the study was to evaluate the potential of Enterobacterial Repetitive Intergenic Consensus (ERIC-PCR) in determining the genetic relationship of Corynebacterium species isolated from different sources. Several protocols that include Restriction Fragment Length Polymorphism (RFLP) [43], Pulse-Field Gel Electrophoresis (PFGE) [44,45], Random Amplified Polymorphic DNA (RAPD) [46,47] have been used to determine the genetic relatedness of Corynebacterium species. However, it has been reported that Corynebacterium pseudotuberculosis isolates from different animal species produced very closely related ERIC patterns regardless of the country in which they were isolated [45]. Similar observations were obtained in the present study. On the contrary, 10 RAPD fingerprints of Corynebacterium pseudotuberculosis from horses, cattle and sheep in the USA were obtained in another study [46]. ERIC-PCR has been used successfully for genotyping of bacteria species and the detection of strain diversity within a known population [48]. In the present study ERIC PCR effectively determined the genetic patterns of isolates from different areas.

\section{Conclusion and Recommendations}

The findings suggest the presence of Corynebacterium species from raw mutton and lamb that is sold in some supermarkets and butcheries within selected areas in the North West Province. Due the fact that some diseases caused by Corynebacterium species have been found to occur through the consumption of contaminated food products, this can also pose a health risks to consumers who prefer their meat undercooked especially immunocompromised individuals and those who live in poverty driven rural communities. The isolation of Corynebacterium species from mutton and lamb raises the need for further studies which will determine the occurrence and virulent gene profiles of this species in food products. Such a study will ensure public health in the North West Province, since foodborne diseases are a growing public health problem worldwide.

\section{Acknowledgement}

We gratefully acknowledge Mr. B.J Morapedi for his assistance during the collection of samples and Mrs Huyser Rika for technical assistance during this study. This study was financially supported by Department of Biological Sciences, North West University and the North West University Postgraduate Merit Bursary.

\section{References}

[1] Smith, K.F. and Oram, D.M., Corynebacteria (including diphtheria). Encyclopedia of Microbiology. University of Maryland, Baltimore, MD, USA. 94-106. 2009.

[2] Aravena-Roman, M., Spröer, C., Siering, C., Inglis, T., Schumann, P. and Yassin, A.F., "Corynebacterium aquatimens species Novel, a lipophilic Corynebacterium isolated from blood culture of patient with bacteremia”, Syst Appl Microbiol 35(6). 380-384. 2012.

[3] Rikitomi, N., Nagatake, T., Matsumoto, K., Watanabe, K. and Mbaki, N., "Lower Respiratory Tract Infections Due to NonDiphtheria Corynebacteria in 8 Patients with Underlying Lung Diseases”, Tohoku J Exp Med 153(4). 313-325. 1987.

[4] Janda, W.M., "Corynebacterium Species and the Coryneform Bacteria Part I: New and Emerging Species in the Genus Corynebacterium”, Clin Microbiol Newsletter 20(6). 41-52. 1998.

[5] Paviour, S., Musaad, S., Roberts, S., Taylor, G., Taylor, S., Shore, K., Lang, S. and Holland, D., “Corynebacterium Species Isolated from Patients with Mastitis”, Clin Infect Dis 35(11). 1434-1440. 2002.

[6] Fernández-Garayzabal, J.F., Vela, A.I., Egido, R., Hutson, R.A., Lanzarot, M.P., Ferna'ndez-Garcı'a, M. and Collins, M.D., "Corynebacterium ciconiae species Novel isolated from the trachea of black storks (Ciconia nigra)”, Int J Syst Evol Microbiol 54. 2191-2195. 2004.

[7] Schiffl, H., Mucke, C. and Lang, S.M., "Exited Site by NonDiphtheria Corynebacterium in CAPD”, Perit Dial Int 24. 454459. 2004.

[8] Shukla, S.K., Harney, M., Jhaveri, B., Andrews, K. and Reed K.D., Is a Black-Pigmented Corynebacterium Species an Opportunistic 
Pathogen during Pregnancy? Literature Review and Report of 3 New Cases”, Clin Infect Dis 37. 834-837. 2003.

[9] Hart, R.J., "Corynebacterium ulcerans in humans and cattle in North Devon”, J Hyg 92(2). 161-164. 1984.

[10] Hommez, J., Devriese, L.A., Vaneechoutte, M., Riegel, P., Butaye, P. and Haesebrouck, F., "Identification of Nonlipophilic Corynebacteria Isolated from Dairy Cows with Mastitis”, J Clin Microbiol 37(4). 954-957. 1999.

[11] Vasut, R.G. and Robeci, M.D., "Food Contamination with Psyhcrophilic Bacteria”, Lucr St Med Vet Timisoara 13(2). 325330. 2009.

[12] Frederick, A., Ayum, T.G., Gifty, A.A. and Samuel, A., "Microbial quality of chevon and mutton sold in Tamale Metropolis of Northern Ghana”, J Appl Sci Environ Manage 14(4). 53-55. 2010

[13] Muller, B., de Klerk-Lorist, L., Henton, M.M., Lane, E., Parsons, S., Gay van pittius, N.C., Kotze, A., Van Helden, P.D. and Tanner, M., "Mixed infections of Corynebacterium pseudotuberculosis and non-tuberculosis mycobacteria in South African antelopes presenting with tuberculosis-like lesions”, Vet Microbiol 147(3). 340-345. 2011.

[14] Bastos, B.L., Portela, R.W.D., Dorella, F.A., Ribeiro, D., Seyffert, N., Castro, T.L de P., Miyoshi, A., Oliveira, S.C., Meyer, R. and Azevedo, V., "Corynebacterium pseudotuberculosis: Immunological Responses in Animal Models and Zoonotic Potential”, J Clin Cell Immunol S4. 005. 2012.

[15] Suvajdzic, L., Potkonjak, A., Milanov, D., Lako, B., Kocic, B., Milic, N. and Cabarkapa, I., "A Proposal of a Diagnostic Protocol for Isolation of Corynebacterium ulcerans from Cow's Milk”, Acta Sci Vet 40(2). 1039. 2012.

[16] Efstratiou, E. and George, R.C., "Laboratory guidelines for the diagnosis of infection caused by Corynebacterium diphtheria and Corynebacterium ulcerans", Commun Dis Pub Health 2(4). 250257. 1999.

[17] Vaneechoutte, M., Riegel, P., de Briel, D., Monteil, H., Verschraegen, G., De Rouck, A. and Claeys, G., "Evaluation of the applicability of amplified rDNA-restriction analysis (ARDRA) to identification of species of the genus Corynebacterium", Res Microbiol 146(8). 633-641. 1995.

[18] Guimarães, A., Dorneles, E.M., Andrade, G.I., Lage, A.P., Miyoshi, A., Azevedo, V., Gouveia, A.M. and Heinemann, M.B. "Molecular characterization of Corynebacterium pseudotuberculosis isolates using ERIC-PCR”, Vet Microbiol 153(3-4). 299-306. 2011.

[19] Mattos-Guaraldi, A.L., Pimenta, F.P., Matias, G.A.M., Pereira, G.A., Camello, T.C.F., Alves, G.B., Rosa, A.C.P. and Hirata, R., "A PCR for dtxR gene: Application to diagnosis of non-toxigenic and toxigenic Corynebacterium diphtheriae", Mol Cell probes 22(3). 189-192. 2008.

[20] Tanner, M.A., Shoskes, D., Shahed, A. and Pace, N.R., "Prevalence of Corynebacterial 16S rRNA sequences in patience with bacterial and "nonbacterial" prostatitis", J Clin Microbiol 37(6). 1863-1870. 1999.

[21] Gao, B. and Gupta, R.S., "Phylogenetic framework and molecular signatures for the main clades of the phylum Actinobacteria”, Microbiol Mol Biol Rev 76(1). 66-112. 2012.

[22] Javanbakht, J., Tehrani, L., Hassan, M.A.M., Zamani, M. Rajabian, M., Akbari, H. and Shafei, R., "Histopathological and bacteriological study on hepatic abscesses of herrik sheep”, J Med Microbiol Diag 1(4). 1-4. 2012.

[23] Funke, G., von Graevenitz, A., Clarridge, J.E. and Bernard, K.A., "Clinical Microbiology of Coryneform Bacteria”, Clin Microbiol Rev 10(1) 125-159. 1997.

[24] Kidanemariama, A., Gouws, J., van Vuurenb, M. and Gummowc, B., "Ulcerative balanitis and vulvitis of Dorper sheep in South Africa: a study on its aetiology and clinical features”, J S Afr Vet Assoc 76(4). 197-203. 2005.

[25] Liebenberg, S.J.R., White, W.A. and Fagan, J.J., “A case report of an 11 year old boy with a fatal sore throat: Corynebacterium diphtheriae - does it still occur?”, South Afr J Epidemiol Infect 24(4). 40-42. 2009.

[26] Leask, R., Blignaut, B.J.C. and Grobler, M.J., “Corynebacterium pseudotuberculosis associated with otitis media-interna in goats”, J S Afr Vet Assoc 84(1). 1-3. 2013.

[27] Golub, B., Falk, G. and Spink, W.W., "Lung Abscess Due to Corynebacterium equi: Report of First Human Infection”, Annals Intern Med 66(6). 1174-1177. 1967.
[28] Peel, M.M., Palmer, G.G., Stacpoole A.M. and Gerr, T.G., "Human Lymphadenitis Due to Corynebacterium pseudotuberculosis: Report of Ten Cases from Australia and Review”, Clin Infect Dis 24. 185-191. 1997.

[29] Osman, S.A., Al-Gaabary, M.H., Ahmed, M.S. and Oreiby, A.F. "Abattoir survey on caseous lymphadenitis in sheep and goats in Tanta, Egypt”, Small Rum Res 94. 117-124. 2010.

[30] Contzen, M., Sting, R., Blazey, B. and Rau, J., “Corynebacterium ulcerans from diseased wild boars”, Zoonoses Public Health 58(7) 479-488. 2011.

[31] Sood, N.K., Sandhu, B.S., Gupta, K., Narang, D., Vasudeva, K. and Singth, N.D., "Mesenteric caseous lymphadenitis in cow calf caused by Corynebacterium pseudotuberculosis: a case report”, Vet Med 57(7). 371-375. 2012.

[32] Ahmed, A-H., Saad, N.M., Wahba, N.M. and Mosa, A.I.H., "Polymerase Chain Reaction for Detection of Toxigenic Strains of Corynnebacterium diphtheria in Milk and Some Milk Products”, Int J Dairy Sci 6 (5). 287-294. 2011.

[33] Çetinkaya, B., Karahan, M., Atil, E., Kalin, R., De Baere, T. and Vaneechoutte, M., "Identification of Corynebacterium pseudotuberculosis isolates from sheep and goats by PCR", Vet Microbiol 88. 75-83. 2002.

[34] Guimarães, A.S., Seyffert, N., Bastos, B.L., Portela, R.W.D., Meyer, R., Carmo, F.B., Cruz, J.C.M., McCulloch, J.A., Lage, A.P., Heinemann, M.B., Miyoshi, A., Azevedo, V. and Gouveia, A.M.G., "Caseous lymphadenitis in sheep flocks of the state of Minas Gerais, Brazil: prevalence and management surveys”, Small Rumin. Res 87. 86-91. 2009.

[35] Paton, M.W., Mercy, A.R., Wilkinson, F.C., Gardner, J.J., Sutherland, S.S., Ellis, T.M., "The effects of caseous lymphadenitis on wool production and bodyweight in young sheep”, Aust Vet J 65. 117-119. 1988.

[36] Thomas, M., Siji, P.C., Preji, T., Nanu, E. and Thomas F., "Milk Born Bacterial Zoonosis”, Instas Polivet 7(2). 212-218. 2006.

[37] Lowe, C.F., Bernard, K.A. and Romney, M.G., "Cutaneous Diphtheria in the Urban Poor Population of Vancouver, British Colombia, Canada: a 10- Year Review”, J Clin Microbiol 49(7). 2664-2666. 2011.

[38] Freney, J., Duperron, M.T., Courtier, C., Hansen, W., Allard, F., Boeufgras, J.M., Monget, D. and Fleurette, J., "Evaluation of API Coryne in Comparison with Conventional Methods for Identifying Coryneform Bacteria”, J Clin Microbiol 29(1). 38-41. 1991.

[39] Dabassa, A., "Evaluation of Home Slaughtered Meat Quality used for Human Consumption at Household and Food Seller House in Jimma”, World J Med Sci Res 1(3). 038-043. 2013.

[40] Roux, V., Drancourt, M. and La Scola, B., "Corynebacterium Species Isolated from Bone and Joint Infections Identified by $16 \mathrm{~S}$ rRNA Gene Sequence Analysis”, J Clin Microbiol 42(5). 22312233. 2004.

[41] Khamis, A., Raoult, D. and La Scola, B., "rpoB Gene Sequencing for Identification of Corynebacterium species”, J Clin Microbiol 42(9). 3925-3931. 2004.

[42] Mart́n, J.F., Barreiro, C., González-Lavado, E. and Barriuso, M., "Ribosomal RNA and ribosomal proteins in Corynebacteria", J Biotechnol 104(1-4). 41-53. 2003.

[43] Bjorkroth, J., Korkeala, H. and Funke, G., "rRNA gene RFLP as an identification tool for Corynebacterium species”, Int. J. Syst. Bacteriol. 49. 983-989. 1999.

[44] Connor, K.M., Quirie, M.M., Baird, G. and Donachie, W., "Characterization of United Kingdom isolates of Corynebacterium pseudotuberculosis using pulsed-field gel electrophoresis”, J. Clin. Microbiol. 38. 2633-2637. 2000

[45] Connor, K.M., Fontaine, M.C., Rudge, K., Baird, G.J. and Donachie, W., "Molecular genotyping of multinational ovine and caprine Corynebacterium pseudotuberculosis isolates using pulsed-field gel electrophoresis”, Vet. Res. 38, 613-623. 2007.

[46] Foley, J.E., Spier, S.J., Mihalyi, J., Drazenovich, N. and Leutenegger, C.M., "Molecular epidemiologic features of Corynebacterium pseudotuberculosis isolated from horses", Am. J. Vet. Res. 65. 1734-1737. 2004.

[47] Stefańska, I., Rzewuska, M. and Binek, M., "Evaluation of three methods for DNA fingerprinting of Corynebacterium pseudotuberculosis strains isolated from goats in Poland”, Polish J. Microbiol. 57. 105-112. 2008.

[48] Li, W., Raoult, D. and Fournier, P.E., "Bacterial strain typing in genomic era”, FEMS. Microbiol. Rev. 33. 892-916. 2009. 